\title{
Programs and Instruments for Promoting Innovation with Technology-Based Companies in Brazil
}

\author{
Diogo Bezerra Borges ${ }^{1}$, Paula Meyer Soares ${ }^{2}$, Marcelo Santana Silva ${ }^{3^{*}}$
}

\begin{abstract}
The need to stimulate technological entrepreneurship has been one of the biggest challenges faced in Science, Technology and Innovation Policies in Brazil. Therefore, the present research sought to carry out a comparative study of different programs and instruments to foster innovation for smaller companies coordinated by the Federal Government and operated through its Autarchies, Public Companies and Social Organizations. The following programs were used as research objects: (1) STARTUP BRAZIL; (2) STARTUP-INDUSTRY CONNECTION; (3) EMBRAPII - SEBRAE PROGRAM; (4) FINEP STARTUP; (5) STARTUP - INDUSTRY CONNECTION 4.0; (6) CONECTA STARTUP BRAZIL. We sought to investigate the following aspects: (1) proposed objectives; (2) profiles of targeted companies; (3) promotion frequency; (4) available financial resources; (5) fostering technological cooperation with STIs, and (6) mobilization of actors from innovation ecosystem. The research's results demonstrated that there were upgrades in strategies to foster innovation. New programs started to establish new rules with the purpose of stimulating and/or conditioning partnerships' formation among companies and institutions present in the innovation ecosystem.
\end{abstract}

Keywords: innovation ecosystems; technological entrepreneurship; economic grant; public policies to foster innovation

Submitted: January $25^{\text {th }}, 2021 /$ Approved: July $16^{\text {th }}, 2021$

\section{Introduction}

The historical context has demonstrated the importance of technological entrepreneurship as one of the essential factors for regional and/or national economic development. The development of Silicon Valley demonstrates the relevance of science, technology, and technological entrepreneurship, combined with the participation of risk investors and government support in the consolidation of a technology hub of relevant economic importance, in a region which had no vocation technological whatsoever (Endeavor, 2014).

It is noteworthy that, in addition to Silicon Valley, some academic literature classics have highlighted initiatives adopted by other countries in the development of technology hubs and in the creation of environments favorable to the establishment of technology-based companies. Senor and Singer (2011) reveal how Israeli companies and universities are managed and how governmental public policies are implemented, with emphasis on the establishment of a venture capital fund called Yozma (Senor \& Singer, 2011). Among others, KaiFu Lee (2019) highlights the peculiarities of the competition model of Chinese startups and government policies aimed at supporting technological entrepreneurship (Lee, 2019).

The knowledge of these international experiences aimed at stimulating innovation, reinforces the relevance of programs and instruments to support innovation within the scope of Science, Technology and Innovation Policies in Brazil. Some examples of these policies are: (1) Action Plan in Science, Technology and Innovation 2007 -2011; (2) National Strategy for Science, Technology and Innovation 2012 2015; (3) National Strategy for Science, Technology and Innovation 2016 - 2022 (currently in force) (Mcti, 2010; 2011; 2016).
The implementation of these supporting innovation policies required legislation elaboration by government entities, in order to provide incentives to innovation, and scientific and technological research for the productive sector. To this end, the Innovation $\mathrm{Law}^{1}$ was drafted, which regulates resources transfer through economic subsidies to companies, among others (Morais, 2007). Until then, the instrument type used to support research and technological development projects for companies' benefit occurred through a Scientific and Technological Institution - STI (CGEE, 2009).

In the initial years that followed the Innovation Law, the Financing Agency for Studies and Projects - FINEP made frequent use of this instrument, both through call for projects directed at companies of any size (micro and small companies included), as well as through programs directed exclusively at smaller companies, such as: the Support Program for Innovation in Micro and Small Enterprises - TECNOVA, PAPPE Subvention and PAPPE Integration. In addition to these programs, the Federal Government issued call for cooperative projects involving research institutions and companies by means of non-reimbursable resources, subsidized financing lines, etc (Morais, 2007).

However, the respective initiatives were limited to financial support for research and technological development activities. Little relevance was given to participation of other innovation ecosystem's actors, such as angel investors, incubators, accelerators, among others. It is understood that these institutions play a fundamental role for technology-based startups, through mentoring, consultancy and financial support from venture capital (Borges, 2015).

In recent years, it has been found that Federal Government initiatives have been showing relevant changes in order to establish rules

(1) Innovation Department. Ministry of Science, Technology and Innovation (MCTI), Brasília, Brazil

(2) Master's course in Innovation and Technology Transfer (PROFNIT), University of Brasilia (UnB), Brasilia, Brazil

(3) Master's course in Innovation and Technology Transfer (PROFNIT), Federal Institute of Bahia (IFBA), Salvador, Brazil

*Corresponding author: marcelosilva@ifba.edu.br

${ }^{1}$ Law No. 10,973/2004. Also known as the Legal Framework for Science, Technology and Innovation, it was created with the aim of stimulating partnerships among academic institutions and the Brazilian productive sector.

ISSN: 0718-2724. (http://jotmi.org)

Journal of Technology Management \& Innovation (c) Universidad Alberto Hurtado, Facultad de Economía y Negocios. 
and requirements that condition or encourage participation of different actors in the innovation ecosystem. Understanding them, from a historical viewpoint, will contribute to future academic papers that have as their research object initiatives to foster innovation. To this end, a comparative study of recent initiatives coordinated by the Federal Government and operated through its Autarchies (CNPq), Public Companies (FINEP) and Social Organizations (EMBRAPII and ABDI) was carried out.

This article is structured in four sections, the first one deals with the innovation role as an initiative to induce economic development of nations, and how business strategies can rely on innovation to remain active in the market. The second section provides a panoramic analysis of the ST\&I policy evolution in the national development model, in each of the main phases of Brazilian development. The third section introduces promotion programs and their main characteristics with regard to the amount of allocated funds, requirements of proposing companies, actors involved, etc. Finally, the conclusions of the present work are presented in the fourth section.

\section{Theoretical Reference}

\subsection{Innovation as a strategic factor for economic development}

Technological innovations marked an important component in the progress of human societies. The gunpowder discovery by the Chinese, the airplane invention and even the machinery developed during the Industrial Revolution Period are some examples of creations, discoveries and innovations that contributed to economic and social transformations (Trott, 2012). In this context, some literature classics highlight the importance of technological innovation in economic growth, such as Schumpeter's work called "Theory of Economic Development", first published in 1911. Freeman and Soete (2008) related scientific basis technologies to its impacts on microeconomics and macroeconomics, in addition to public policies' role in innovation promoting process (Freeman \& Soete 2008).

Porter's claims (1999) also highlighted the important role of technological innovation in a context of competitive advantage among different nations. According to the author, a nation's prosperity is not something inherited or even derived from a country's natural endowments. Nevertheless, it is due to the ability of companies to achieve competitive advantage through innovation initiatives (Porter, 1999).

In fact, innovations are crucial to business sector's competitiveness, as they differentiate their products and services from competitors, creating additional or new value for customers. Firms innovate in order to stay on the market and to maximize their profits. Innovation is the main mechanism for a company to create or gain competitive advantage. Competitive advantage is achieved when the organization implements a strategy or an innovation capable of creating value for the market (Conto, S.M. et al., 2014). A nation that is strengthened through investments in science, technology and innovation has contributed to its competitiveness in the international market (Alencar \& Rocha, 2018).
Such understanding is evident in Christensen's work (2012). The respective author cites cases of leading companies that lost growth and profit opportunity to smaller competitors that entered the market with innovative products, processes and business models (Christensen, 2012). In this perspective, the government's role as a driving agent of innovation process in a country has become crucial. It has the role of establishing a set of policies that contribute to optimize competitive performance of strategic and priority sectors (Porter, 1999).

From this perspective, other authors have highlighted government role in stimulating innovation. Mazzucato (2011) highlights State's strategic importance in development of major technological advances. However, a key problem reported by the author refers to knowledge lack of the State as an entrepreneurial agent, even today.

Aligned with Mazzucato's positioning (2011), Etzkowitz's Triple Helix model (2013) reinforces the importance of the relationship among government, university and industry as a key factor for fostering innovation and for a knowledge-based economy growth. The author has emphasized that the objective of developing this model is to ensure that innovation dynamics contribute to the consolidation of a knowledge-based economy (Etzkowitz, 2013).

In the Brazilian context, Jaroszewski (2018) highlights that the government has been able to structure joint actions with university and business propellers. Despite advances, there have not yet been enough results to the point that the government establishes itself as an Entrepreneurial State capable of a more significant role in conducting innovation policy (Jaroszewski, 2018).

Different stages of an innovation process require different financial commitments in view of necessary investment and present uncertainty. This reinforces governments' involvement, directly or indirectly, in promoting research and technological development activities. The most used mechanisms include a combination of "seed funding" granting and loans offered by development banks (UNCTAD, 2018). Government support becomes relevant, especially in early stages of high uncertainty, through non-repayable funds. In later stages, a company would count on support for promotion through venture capital and repayable financing modalities (Santana et al., 2018).

Facing this challenge, several countries took the initiative to create investment programs in venture capital aimed at Technology-Based Companies. As an example, there are the American government initiatives named: (1) Small Business Innovation Research (SBIR), and (2) Small Business Technology Transfer (STTR). These are highly competitive programs that encourage small national companies to get involved in federal research and development activities with potential for commercialization (SBIR, 2020).

\subsection{Evolution of Science and Technology Policies in Brazil}

The period from 1950 to 1980 is marked by a process called "Development Via Growth". During this period, the State protected emerging industry, supported private national and foreign investments and created public companies in sectors, considered strategic for national deve- 
lopment (Viotti, 2008). To this end, a policy aimed at replacing imports and expanding exports of manufactured goods was institutionalized. Therefore, it was intended to bring national industry structure into line with industrialized economies' standard (Suzigan \& Furtado, 2006).

In parallel, an S\&T policy was in force for strengthening infrastructure, and research and development activities, such as: creation of universities, research institutes, and human resources' training (Viotti, 2008). In this way, an attempt was made to advance the constitution of a National System for Scientific and Technological Development (NSSTD). NSSTD pioneer institutions were CNPq and CAPES, both created in the early 1950s. The creation of FUNTEC, at BNDES, and FINEP date from the 1960s (Suzigan \& Furtado, 2006).

In that time, it was found that the S\&T policy, centered on expanding knowledge supply and disconnected from industrialization process' needs, did not result in significant contributions to development of improvement and innovation capacities. It was noticed that most of the knowledge supply provided by the S\&T policy implementation, did not result in benefits to the productive sector (Viotti, 2008). At that time, there was still no adequate interaction between academia and productive sector. Even today, the relationship between them is considered precarious (Suzigan \& Furtado, 2006).

Soon thereafter, the Phase called "Development via Efficiency" begins, covering the 1980s until the end of 2000. During this period, industrialization policies became responsible for high levels of inefficiency and competitiveness lack of the economy. It was assumed that commercial opening combined with foreign capital inflow would boost the S\&T public policy (Viotti, 2008).

As of 2000, the Phase called "Development via Innovation" began, in which public policies necessary for the country's development were resumed, caring for not replicating previous industrial policies. Among the main actions, it is possible to mention the creation of Sectorial Funds, the Law of Innovation, the Law of Good and the Industrial, Technological and Foreign Trade Policy - PITCE (Viotti, 2008).

In the last decade, it has been noticed that such policies have sought to include the support for technological innovation in the business sector as one of the action axes. Among these, it is possible to mention:

- 2007 -2011 Science, Technology and Innovation Action Plan: it highlighted as one of the challenges the need to increase innovation capacity of the productive sector and to strengthen micro and small companies through programs to support the process of creation and development of innovative companies (Pacti, 2011).

- 2012 - 2015 National Strategy for Science, Technology and Innovation: it cited the need to encourage research, development and innovation activities in micro and small companies through new tax incentives, financing and support, in addition to technological extension (Encti, 2012).

- The current 2016 - 2022 National Strategy for Science, Technology and Innovation: it emphasizes the need to focus on innovation policies' instruments aimed at startups or small companies, instead of investing in the entire set of national firms. To this end, it is necessary to foster innovation and investment ecosystem for this sector with specific programs for entrepreneurship, mentoring and acceleration of companies, such as Startup Brazil, and support for consolidation of financing instruments and venture capital funds (Encti, 2016).

The policy also considers that the main ST\&I financing mechanisms should ensure continuity of existing instruments; expansion of resources for advancing strategic issues; capacity increase to leverage public resources through private investments; and articulation among sector's various instruments. The document also cites the importance of the National Fund for Scientific and Technological Development in promoting ST\&I activities.

\subsection{Technology Based Companies (TBC)}

Technological-based companies whose origin come from experiments and scientific research, whose project involves development and commercialization of technology-based products or services. The fate of these inventions is society (Baeta, Borges, Tremblay, 2005).

Baêta (1999) conceptualizes a company with technological bases to those whose potentials for competitiveness are information and knowledge - specifically, technical and scientific information and knowledge.

In general, technology-based companies use technologies based on intensive knowledge, employing highly qualified labor, graduated from universities and research institutions (Tumelero, 2012).

Technological incubators can be considered a pre-project of future technological companies that will act as creative vectors for innovations. The growing demand for the use of technology is a result of a new economic structure that remodels and modernizes itself every day. Thus, incubators are useful for entrepreneurs to discover innovation's needs and opportunities (Baêta, 1999; Leite, 2006).

In other words, technology-based companies (TBC) are companies in which scientific-technological knowledge is their main production input. In general, TBCs relate to each other and to universities or research institutes. They are also known as high-tech companies. They extensively use laboratories, equipment from research institutions and human capital with expertise in some areas of technological knowledge (Medeiros et al., 1992).

The development of technology-based companies may also originate from companies or organizations whose scope is the expansion of certain technologies. These organizations can be universities, research centers or private companies (Menk, Oliveira Filho, 2008).

According to Freitas \& Muylder (2010), technology-based companies have a set of characteristics to their activity related to exploring opportunities that involve innovation and development of products and services. As mentioned above, generally these companies interact with institutes or institutions that use innovation knowledge as an input for their products' and services' development.

Such characteristics can be presented with the following elements: 
Figure 1. Elements of Technology Based Companies

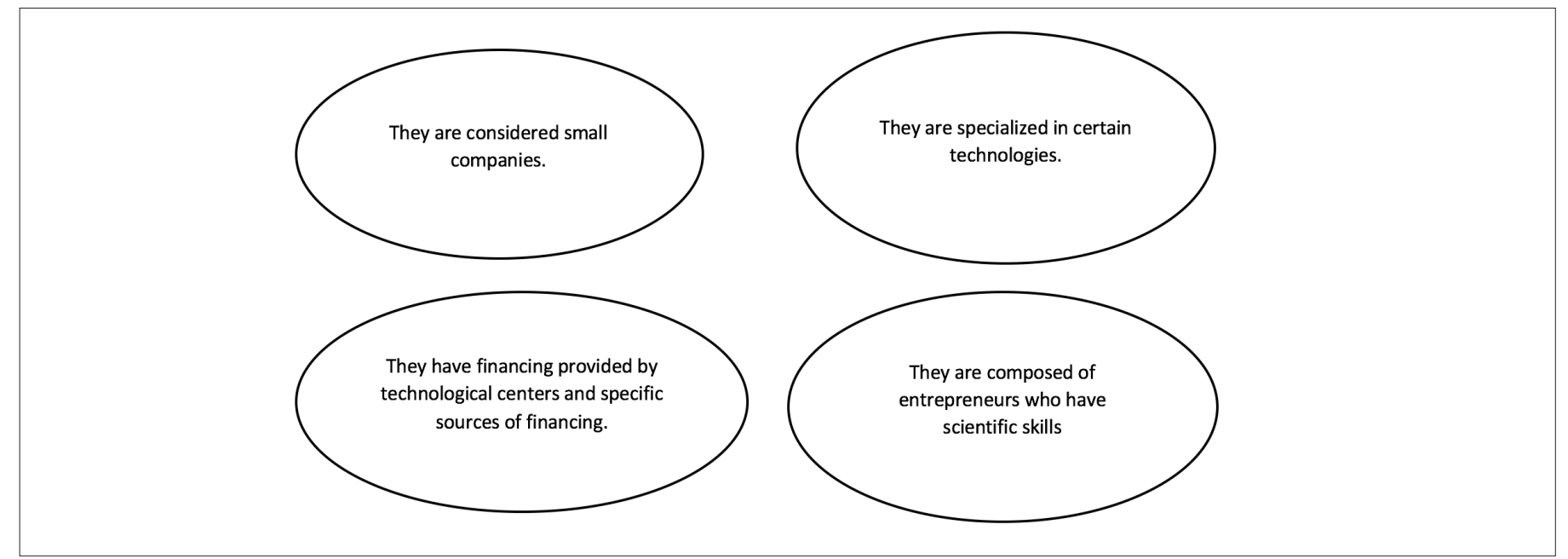

Source: Barbosa et al., (2016)

In general, technology-based companies are small companies that operate exclusively with technology. They are composed of human capital that has technical and professional training focused on an area of technological development. Moreover, these companies operate in line with institutes for promoting technological research. Financial support comes from technological hubs and specific sources of funding.

\section{Research Methodology}

In order to achieve the objective proposed in this research, the methodology used was exploratory, with a qualitative approach, a case study, along with a bibliographic research as the analysis technique (Gil, 1999; Minayo, 2001).

The exploratory character of this work consisted in a preliminary survey of information and data that included bibliographic research on programs and instruments that foster innovation for technology-based companies. It helped to compose a theoretical framework and served as a basis for a critical reflection development on the addressed theme.

According to Minayo (2001), a qualitative research involves understanding factors such as: values and attitudes that permeate the understanding of processes, causes and effects that cannot demonstrate variables' operationalization, that is, they cannot be quantified, because it rather seeks to understand and describe than to predict and explain.

The conduct of the study was based on a multiple case study. As Yin (2008, p.4) mentions, "[..] a case study allows researchers to focus on a "case" and retain a holistic and real world perspective - as in a study of individual life cycles, behavior of small groups, organizational and administrative processes, changing neighborhoods, school performance, international relations and industries' maturation."

According to Yin (2008), the essence of a case study is to try to illuminate a decision or a set of decisions: why they are made, how they are implemented and with what result.
In fact, a case study research aims to understand a real-world phenomenon and to assume that this understanding probably encompasses important contextual conditions relevant to your case (for example, Yin \& Davis, 2007).

Over the years, the Federal Government has been improving its innovation support programs aimed at smaller companies. It is understood that these respective initiatives present different strategies to foster innovation, outlined by means of rules and instruments built from different views and perspectives of government actors involved in public policies' formulation. It is crucial to analyze them from a historical perspective in order to understand their evolution.

The literature review was used as a technique for data collection and analysis. Therefore, data were collected through a process of perceptions' formation about the information related to the main programs coordinated by the Federal Government and operated exclusively through its Autarchies (CNPq), Public Companies (FINEP) and Social Organizations (EMBRAPII and ABDI). Initiatives related to the last two documents that marked out the Science, Technology and Innovation Policy, such as: (1) 2011 - 2015 National Strategy for Science, Technology and Innovation; and (2) 2016 - 2022 National Strategy for Science, Technology and Innovation were evaluated. The year 2019 was established as a limit because the latter policy is still in force.

The programs researched were: (1) STARTUP BRAZIL; (2) STARTUP-INDUSTRY CONNECTION; (3) EMBRAPII - SEBRAE PROGRAM; (4) FINEP STARTUP; (5) CONECTA STARTUP 4.0; (6) CONECTA STARTUP BRAZIL. The following aspects were examined in each of them: (1) proposed objectives; (2) profiles of targeted companies; (3) promotion frequency; (4) available financial resources; (5) fostering technological cooperation with STIs, and (6) ) mobilization of actors from innovation ecosystem, as concisely presented in Chart 1: 


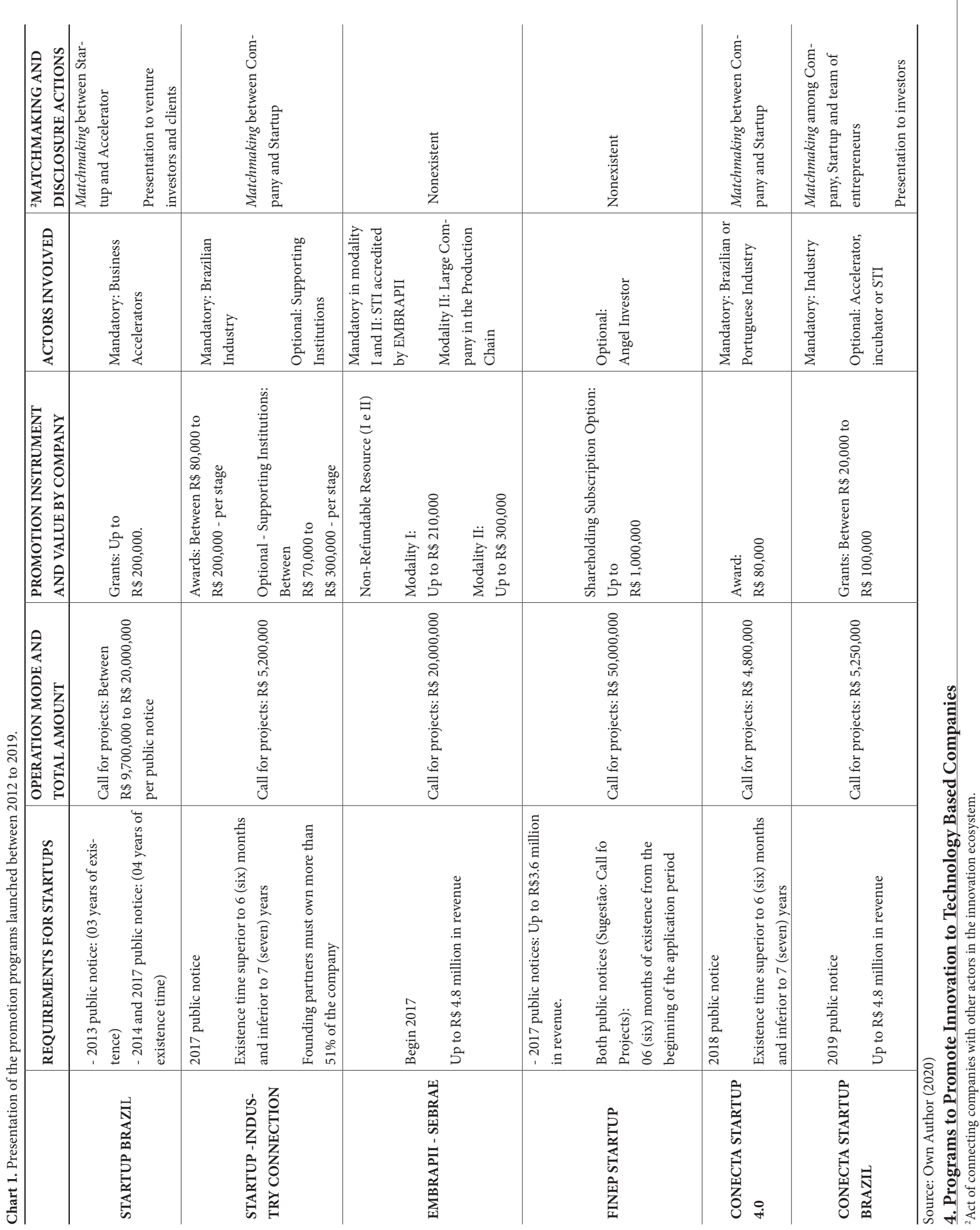




\subsection{STARTUP BRAZIL}

Launched in 2012, the National Program for Startup Acceleration - STARTUP BRAZIL, an initiative of the Ministry of Science, Technology, Innovations and Communications, had the purpose of supporting innovative startups' development that produced software, hardware and information technology services in partnerships with business accelerators. In addition to financial support through grants, selected companies should undergo an acceleration process in which they would be involved in mentoring activities, market access support and fund raising from investors (Enap, 2016).

\subsubsection{Profiles of aimed companies, available financial resources and promotion frequency}

The program operated through public calls, the first one aimed to qualify and enable business accelerators, and the second one meant to carry out the selection of startups. The first editions of public calls were aimed at startups from any country that developed an innovative solution in software, hardware and/or IT services, with $25 \%$ of vacancies destined to international startups. Financial support was provided through grants to promote technological development via the National Council for Scientific and Technological Development - CNPq. Proposals' requests had a maximum value of $\mathrm{R} \$ 200,000$, which varied between $\mathrm{R} \$ 250.00$ to $\mathrm{R} \$ 8,000.00$ monthly, according to activities' needs pointed out by each project (Softex, 2019).

A total of $\mathrm{R} \$ 14,000,000$ was estimated for execution between 2013 and 2014 for the program's first edition. Out of this amount, 30\% was allocated to proposers based in the North, Northeast and Center-West regions. As a program's requirement, companies that were willing to participate should present up to three years of existence (Cnpq, 2013). In order to expand the program's scope, the second edition presented some changes. First, resources contribution was increased to $\mathrm{R} \$ 20,000,000$, as well as the number of accelerators: from nine to twelve. Furthermore, business accelerators were required to make a minimum contribution of $\mathrm{R} \$ 20,000$ per startup, in addition to the commitment to accelerate three companies at least. Moreover, participation of companies that were already in the acceleration process by any of the accelerators qualified by the program was denied.

Additionally, the maximum startup existence time was extended from three to four years. In the program's third edition, no significant changes were made, except for the establishment of a $20 \%$ maximum limit of accelerators' shareholding in supported companies. The call for qualification of accelerators occurred in the second half of 2014. However, only in 2017 the public notice for startups projects was launched, with an estimated value of $\mathrm{R} \$ 9,700,000$ (Enap, 2016).

\subsubsection{Fostering technological cooperation and mobilizing actors from innovation ecosystem}

As highlighted above, the Startup Brazil Program operated through payment of grants to new technology-based companies, from which companies could strengthen their technical staff of professionals. Although a grant is a very common financial support instrument in the academic environment, the program did not required hiring of researchers or participation of a scientific and technological institution as a partner in the technological development process. On the other hand, a partnership between participating companies and accelerators qualified in the program was required. It is understood that the approximation of nascent technology-based companies to accelerators through acceleration programs would assist them in the phase of product insertion in the market.

Raising funds from risky investments would be another benefit from accelerators' participation in the program. In some editions, it is noteworthy that it was required that they should prove contribution of resources to startups. This would allow private resources' complementation in favor of technological innovation. In addition, the program provided two events to optimize approach process: the first called "Welcome Aboard" with the purpose of presenting startups and accelerators, and the other called "demo day", in which the startups participants would have the opportunity to advertise their technological products and/or services to investors and potential clients at the end of the acceleration process.

\subsection{National Program for Startup-Industry Connection}

Launched in 2016, the National Program for Startup - Industry Connection, an initiative of the Brazilian Agency for Industrial Development - ABDI, sought to connect startups' solutions to industry's real needs. The program's actions were designed to create a favorable environment for disruption, allowing Brazilian startups to develop manufacturing solutions, new businesses, new products, process and service improvements, generating high impact in the industrial context (Abdi, 2019).

\subsubsection{Profiles of aimed companies, available financial resources and promotion frequency}

The Program operated through call for projects in order to select startups that developed projects of interest to participating industries. Launched in 2017, the first notice provided for $\mathrm{R} \$ 5,200,000$ from ABDI's Budget. Unlike Startup Brazil, which operated through grants' payment, this program sought to financial support participating startups through the payment of awards. In return, selected participants should deliver reports that would serve as input for the development of innovation instruments for the industry. Thus, connection processes among industries and startups would be fostered, contributing to the increase of competitiveness and productivity of the Brazilian industry through innovation (Abdi, 2019).

In the public call No. 01/2017, the following requirements were established:

- Industry: Have at least 1 (one) unit or production plant located in the Country so that results obtained with the program would have a greater impact nationally, in addition to having a National Classification of Economic Activities - CNAE 2.0 of divisions 05 to 09 and 10 to 33 (extractive and manufacturing industries) (ABDI, 2019).

- Startups: Existence time of more than 6 (six) months and less than 7 (seven) years. The founding partners should share hold 
more than $51 \%$ of the company's capital, on the application date for this Contest (confirmed through social contract). Moreover, the startup could not be configured exclusively as a commercial representative of non-proprietary technologies (Abdi, 2019).

- Development Support Institution: Existence time superior to 6 (six) months, in order to to prevent inexperienced organizations from participating in the program and not making an effective contribution to the connection process. Additionally, they should declare their financial capacity to meet remuneration model and shareholding proposed in the notice, if they were to select startups (Abdi, 2019).

The contest established a series of steps to be carried out in order for startups to obtain the cash prizes. First, the 40 startups best evaluated in Work Plans would be entitled to an $\mathrm{R} \$ 80,000$ provision in the "matchmaking" phase. In addition, Business Development Support Institutions could contribute between $\mathrm{R} \$ 70,000$ and $\mathrm{R} \$ 120,000$, in favor of each startup (in economic or financial compensation, 70\% of which should be financial). Finally, in the "Business Roundtable" stage, there would be a selection process in which an industry must choose a startup to advance the development of a pilot in order to be potentially acquired by it.

Each selected startup would be awarded the amount of R $\$ 200,000$. Institutions that support business development could complement the contribution of resources with values between $\mathrm{R} \$ 130,000$ to $\mathrm{R} \$ 300,000$ per startup (economic or financial counterpart, $70 \%$ of which should be financial). Due to the financial contribution made, these institutions could claim up to $5 \%$ of the startup's shareholding (Abdi, 2019).

\subsubsection{Fostering technological cooperation and mobilizing actors from innovation ecosystem}

As previously mentioned, the Startup - Industry Connection Program sought to align the development of technological services and/or products from nascent technology-based companies to real needs of the industrial sector. Alike the Startup Brazil Program, participation of Scientific and Technological Institutions was not imposed. However, there was an additional score in the public notice for industries that established partnerships with technological, research or university institutes. The same scoring rule was also considered for Development Support Institutions.

With regard to innovation ecosystem mobilization, the program imposed partnerships between technology providers (startups) and demanders (companies in the industrial sector). In order to optimize this process, the respective program held a series of events and meetings in order to facilitate the process of "matchmaking" between both actors, as previously mentioned. This approach allowed the industrial sector to access several technology-based start-ups with the potential to add competitiveness to their operations. On the other hand, such approach allowed startups to identify potential opportunities for technological development in an industrial environment.
Optionally, the program also sought to mobilize other actors in the innovation ecosystem that could be interested in co-development proposals ${ }^{3}$, as well as making investments in participating startups. The participation of such institutions allowed financial resources' complementation in favor of technological development.

\subsection{EMBRAPII - SEBRAE Program}

Launched in 2017, the respective program is an initiative of the Brazilian Company for Industrial Research and Innovation - EMBRAPII and the Brazilian Company Support Service - SEBRAE. The partnership between the two institutions allowed support for technological development for small businesses through partnerships with research units accredited by EMBRAPII. SEBRAE's participation took place through a financial contribution that complemented the due financial support to smaller companies (Sebrae, 2019).

\subsubsection{Profiles of aimed companies, available financial resources and promotion frequency}

This program was aimed at micro and small companies, individual microentrepreneurs and technology-based startups that were interested in developing innovation projects in partnership with Scientific and Technological Institutions accredited by EMBRAPII. Participating companies should have a National Classification of Economic Activities (CNAE) in industrial area or Information and Communication Technology (ICT) related. Furthermore, it should have revenues of up to $\mathrm{R} \$ 4,800,000$ per year, in addition to being up to date with their fiscal and tax obligations.

Unlike other funding institutions mentioned, EMBRAPII's mode of operation does not occur through call for projects. Primary, the interested company should seek indication of an accredited unit with the appropriate technological competence to execute its project, and then submit the proposal to EMBRAPII. After obtaining a pre-approval, the small business should go to the nearest SEBRAE in order to request a consultancy to prepare a business plan for the proposed technological solution (Sebrae, 2019).

SEBRAE's resources allowed to increase non-reimbursable resources' limit in favor of the development of industrial innovation projects. Projects developed in partnership with a single microenterprise, small business, individual microentrepreneur or startups, and an EMBRAPII Unit would receive SEBRAE's financial contribution of up to $70 \%$ of the company's counterpart in the project, limited to the amount of R\$210,000.

If innovation projects were developed in partnership with an individual microentrepreneur, a startup, a microentrepreneur, a small company or a large company in the production chain, SEBRAE's maximum financial contribution per contracted project would be $80 \%$ of the counterpart of the Individual Microentrepreneur and/or Microenterprise and Small Business, limited to R \$300,000. Complementarily, a counterpart not less than $10 \%$ of the project's total value from medium and large company participating in the project was also required (Embrapii, 2019).

${ }^{3}$ Co-development is a concept that refers to cooperative development among two or more institutions. 
4.3.2 Fostering technological cooperation and mobilizing actors from innovation ecosystem

With respect to encouraging technological cooperation, the instrument's nature used in this program conditions a mandatory participation of a scientific and technological institution in the process of technological development. However, the program is specifically targeted at those institutions previously accredited by EMBRAPII.

Regarding innovation ecosystem's mobilization, "Productive Chaining" modality required the participation of a large company in the production chain. This reinforced the interest in conditioning the development of technological projects that were of interest to large companies.

It is understood that objectives and expected results are similar to those promoted by previous Programs that required collaboration between startups and industries. Finally, it is worth noting that this program did not include events to provide a "matchmaking" process between startups and large industries. Therefore, it was up to companies and accredited units to take the initiative in carrying out actions to articulate and prospect for projects.

\subsection{FINEP STARTUP Program}

This program, an initiative of the Financier of Studies and Projects FINEP, aimed to promote innovation in nascent knowledge-intensive companies. The present program sought to support technologies that were at least in the prototype or testing phase, in addition to have commercial viability. Thus, it should have already made the first sales or that, alternatively, count with a firm, proven purchase/contracting commitments (Finep, 2019).

\subsubsection{Profiles of aimed companies, available financial resources} and promotion frequency

In 2017, FINEP launched two call for projects of the program with a value of $\mathrm{R} \$ 50,000,000$ each with the purpose of providing financial resources to Startups with high growth and return potential in order to successfully face the main challenges of their initial stages of development. The focus was to cover support and financing gap among financial contributions made by acceleration programs, angel investors and crowdfunding tools, and contribution made by Seed Money and Venture Capital Funds. Accordingly, financial support was carried out through the signing of an option to subscribe for a shareholding participation.

Proponent companies that had their projects approved would receive up to $\mathrm{R} \$ 1,000,000$. Those with gross annual operating income less than or equal to $\mathrm{R} \$ 3,600,000$ could participate. In addition, its shareholding control could not be part of a companies' group that had total assets greater than $\mathrm{R} \$ 80,000,000$ or gross annual revenue greater than $\mathrm{R} \$ 100,000,000$ at the end of the previous fiscal year.

Regarding the period of existence, companies should be registered with the Commercial Registry, in the form of a private limited company ("LTDA") or a joint-stock company ("S/A") for at least 6 (six) months from enrollment opening date of the program.
4.4.2 Fostering technological cooperation and mobilizing actors from innovation ecosystem

As previously mentioned, the FINEP STARTUP program sought to support companies that developed technologies that were already in prototype or testing phases. The program's selection process defined some evaluation parameters in order to encourage technological cooperation. Among them, there is the "Innovation" criterion whose one of evaluation aspects is the establishment of partnerships for innovation, such as service and cooperation contracts with Scientific and Technological Institutions. However, there was no specific score for this item, therefore it is possible to state that the program actually stimulated technological cooperation.

Regarding mobilization of ecosystem players, the respective program stimulated optional participation of risk investors. To this end, additional scoring rules were established in the selection process for companies that presented a commitment to invest resources by angel investors. Finally, the program did not provide for events that would allow developed technologies' presentation to the market or risk investors.

\subsection{Startup Connection 4.0 Program}

In 2018, ABDI launched the Startup Connection 4.0 Program with the purpose of stimulating open innovation with a focus on its challenges in industry 4.0 and digital integration of value chain stages (ABDI, 2019).

\subsubsection{Profiles of aimed companies, available financial resources and promotion frequency}

Unlike the Startup - Industry Connection Program, the present program innovated by contemplating participation of foreign industries and startups. In the Startup 4.0 Connection's call for projects, $\mathrm{R} \$$ 4,800,000 was foreseen aiming at rewarding 60 (sixty) startups (Brazilian or Portuguese) with the amount of $\mathrm{R} \$ 80,000$ (Abdi, 2019). To this end, a selection process was established in which Brazilian or Portuguese startups and industries should meet the following requirements:

- Brazilian Industry: Brazilian company which should be classified as an extractive and manufacturing industry in the Country (Abdi, 2019).

- Portuguese Industry: Portuguese company which should be classified as an extractive, manufacturing and energy industry in Portugal (Abdi, 2019).

- Brazilian Startup: a technology-based organization which should have technological innovation as a foundation part of its competitive strategy, designed to seek a repeatable, scalable product, service or business model with high growth potential, under extreme uncertainty conditions. The startup should have a period of existence of more than 6 (six) months and less than 7 (seven) years (Abdi, 2019).

- Portuguese Startup: a technology-based organization which should have technological innovation as a foundation part of its competitive strategy, designed to seek a repeatable, scalable product, service or business model with high growth potential, under 
extreme uncertainty conditions. The startup should be constituted under Portuguese laws, with headquarters and administration in the country, in addition to a period of existence of more than 6 (six) months and less than 7 (seven) years (Abdi, 2019).

\subsubsection{Fostering technological cooperation and mobilizing actors} from innovation ecosystem

Similar to the Startup - Industry Connection Program, Startup 4.0 required that the development of technological services and/or products originated from nascent technology-based companies should meet real needs of the industrial sector. Therefore, rules that structure mutual technological development among the industrial sector and startups were maintained, as well as the holding of events and meetings aiming at facilitating the "matchmaking" process.

Alike the Startup - Industry Connection Program, no rules were established to require a mandatory participation of scientific and technological institutions in technological development process. However, additional scores were established in the selection process for interested industries that presented the establishment of partnerships with technological, research or university institutes. Finally, unlike the Startup - Industry Connection Program, Startup 4.0 did not involve participation of Development Support Institutions.

\subsection{CONECTA STARTUP BRAZIL}

The Conecta Startup Brazil arose from a joint initiative between the National Agency for Industrial Development - ABDI and the Ministry of Science, Technology, Innovations and Communications MCTIC. The Conecta Startup Brazil Program was designed for the development and creation of technology-based businesses through connection of entrepreneurs to technological demands. The Program sought to select Entrepreneurial Teams and/or Startups in the early stage, in addition to Companies in the productive sector (Abdi, 2019).

\subsubsection{Profiles of aimed companies, available financial resources and promotion frequency}

The Conecta Startup Brazil Program emerged with the purpose of closing relationship gaps among startups and the market, thanks to lessons learned from previous programs: the Startup Brazil Programs and the National Program for Startup - Industry Connection. The total amount allocated to the Program was $\mathrm{R} \$ 5,250,000$, coming from the budget of the Ministry of Science, Technology, Innovations and Communications - MCTIC, and the National Council for Scientific and Technological Development - CNPq.

In addition to startups, companies that: (1) were part of the productive sector; (2) were installed in Brazil; (3) showed interest in sharing problems and demands, as well as mentoring, testing and co-developing technological solutions applied to their needs along with the selected startup, could also participate. Regarding participation requirements, it was required that Entrepreneurial Teams and/or Startups in the early stage did not have a corporate bond with companies whose revenue exceeded $\mathrm{R} \$ 4,800,000$ per year (Abdi, 2019).
Alike the Startup Brazil Program, the Conecta Startup Brazil operated through the payment of grants to startups, as long as they fulfilled some phases. "Conceptualization" was one of them, which involved the initial stage of building process of a startup by individuals who had an interest in undertaking. Therefore, real problems' identification were sought through connection with challenges and transformation of ideas into business. In this phase, startups would receive up to $\mathrm{R} \$ 20,000$ for a solution development.

The phase defined as "Validation" consisted in a Minimum Viable Product - MVP ${ }^{4}$ development in order to demonstrate the business value proposal and its respective presentation in a validation process with the market. In this phase, startups would receive up to $\mathrm{R} \$ 30,000$.

The "Practical" phase consisted in a business development evolution through experiments by the target audience. In this phase, startups would be entitled to up to $\mathrm{R} \$ 50,000$. At the end of the Practical phase, Entrepreneurial Teams and/or Startups in the early stage should make a presentation to private investors with possibility of receiving an investment of up to $\mathrm{R} \$ 100,000$ (Abdi, 2019).

\subsubsection{Fostering technological cooperation and mobilizing actors from innovation ecosystem}

As previously mentioned, the present program is the result of efforts to improve previous initiatives. In general, the Conecta Startup Brazil maintained some points in common to some previous programs, such as the establishment of partnerships among startups and industries. Another similar point concerns the realization of events with the purpose of facilitating "matchmaking" process among participating actors, in addition to events that allowed developed technologies' presentation to investors. Finally, there was no factor that required mandatory participation of scientific and technological institutions. However, different scoring rules were established for proposing industries that demonstrated partnerships establishment with research and development institutes.

\section{Results and Discussions}

Over the years, the Federal Government has been improving its innovation support programs aimed at smaller companies. It is crucial to analyze them from a historical perspective to understand their evolution. Based on a literature review, it was possible to analyze the main aspects of programs coordinated by the Federal Government, launched in recent years.

Regarding the proposed objectives, it was possible to verify some similarities and distinctions in the innovation strategies outlined by actors involved in public policies' formulation. In the case of STARTUP BRAZIL, the program proposed to support growth of innovative startups that developed software, hardware and information technology services, regardless of participation of an anchor company.

In contrast, programs coordinated by ABDI, such as STARTUPINDÚSTRIA, STARTUP 4.0 and CONECTA 4.0, sought to connect

${ }^{4} \mathrm{MVP}$ - Product's simpler version to be made commercially available by the company 
startups' solutions to industry's real needs. The actions of the programs were aimed at creating an environment that would allow Brazilian startups to develop solutions applied to the industrial sector.

In the case of the EMBRAPII - SEBRAE Program, efforts were made to allow technological development support to small businesses through partnerships with accredited research units. One of the support modalities also sought to support technological chain with an anchor company's participation, such as programs coordinated by ABDI.

In contrast to previous programs, FINEP STARTUP targeted knowledge-intensive startups, covering the support and financing gap among contributions made by acceleration programs, angel investors and crowdfunding tools, and contributions made by Seed Money and Venture Capital.

Regarding profile delimitation of participating companies in innovation strategies, the institutions established three types of requirements: (1) based exclusively on existence time; (2) based exclusively on annual revenue; (3) based on both, existence time and annual revenue. Programs such as STARTUP BRAZIL, STARTUP-INDÚSTRIA and STARTUP-INDÚSTRIA 4.0 established the maximum existence time between 03 to 07 years and in some cases, the minimum time of 06 months.

In other programs, participation requirements for companies were limited exclusively to a maximum revenue, such as the CONECTA STARTUP BRAZIL and EMBRAPII - SEBRAE Programs. Both established an annual revenue of up to $\mathrm{R} \$ 4,800,000$ as a requirement. It is worth mentioning that this value is the maximum revenue established for small companies, as defined in Complementary Law No. $123 / 2006$, which establishes the National Statute of Micro and Small Enterprises (Brasil, 2006).

Finally, it was found that one of the programs established as requirements both a minimum existence time and an annual revenue. Such is the case of FINEP STARTUP Program, in which a minimum of 06 months of existence time, in addition to an annual revenue of up to $\mathrm{R} \$ 3,600,000$ were required for participating companies.

Regarding operation mode, the use of call for projects as a strategy for promoting and selecting projects was predominant, except for the EMBRAPII - SEBRAE Program. This latter managed to prospect projects through Accredited Units, in which the amount of R $\$ 20,000,000$ was made available. In relation to the programs that were operated through call for projects, it was found that the amount of allocated resources did not suffer great variations to those that included a connection among startups and industries, such as STARTUP-INDUSTRY, STARTUP-INDUSTRY 4.0, and CONECTA STARTUP BRAZIL.

In such cases, funds' amount ranged from $\mathrm{R} \$ 4,800,000$ to $\mathrm{R} \$ 5,250,000$. In the case of STARTUP BRAZIL, it was possible to verify that this value ranged from $\mathrm{R} \$ 9,700,000$ to $\mathrm{R} \$ 20,000,000$. However, the largest contribution of resources was in the FINEP STARTUP Program, in which $\mathrm{R} \$ 50,000,000$ were made available.
Regarding strategies to foster innovation, there were some similarities and distinctions, both in relation to instruments used, as well as to allocation of resources by company adopted among the programs. Some of them adopted an operating strategy through the payment of grants, such as STARTUP BRAZIL and CONECTA STARTUP BRAZIL. In the former, up to R $\$ 200,000$ was allocated per company, while in the latter, the value ranged from $\mathrm{R} \$ 20,000$ to $\mathrm{R} \$ 100,000$.

In the STARTUP INDÚSTRIA and the STARTUP INDÚSTRIA 4.0 programs, an award was used as an incentive instrument. The amount between $\mathrm{R} \$ 80,000$ and $\mathrm{R} \$ 200,000$ was made available per program's stage accomplished in the first program. In addition, participating Support Institutions could supplement with a contribution between $\mathrm{R} \$ 70,000$ to $\mathrm{R} \$ 300,000$, per program's stage accomplished. In relation to the STARTUP INDÚSTRIA 4.0 Program, a payment of up to R\$ 80,000 was established.

In the EMBRAPII - SEBRAE Program, financial contributions were made through non-refundable resources, in which the resource was destined exclusively to an accredited STI, and the maximum contribution varied according to the modality used. In projects developed in partnership with a single microenterprise, small business, individual microentrepreneur or startups and an EMBRAPII Unit, the maximum contribution was $\mathrm{R} \$ 210,000$. However, if a large company in the production chain was part of the project, the respective amount would reach up to $\mathrm{R} \$ 300,000$. In the FINEP STARTUP Program, the option to subscribe for shareholding participation was adopted, in which the maximum contribution of up to $\mathrm{R} \$ 1,000,000$ was foreseen.

It was found that all analyzed innovation promotion programs started to establish rules with the purpose of stimulating or conditioning establishment of partnerships among proposing companies and institutions in the innovation ecosystem, and in some cases, technological cooperation among proposing companies and universities or research institutions. It is understood that such actions are part of a strategy to enhance programs' effectiveness to foster innovation.

In the STARTUP BRAZIL Program, partnership's establishment among participating companies and accelerators qualified in the program was conditioned. Three other programs conditioned the industrial sector's participation in the innovation process, they were: STARTUP - INDUSTRY CONNECTION, STARTUP - INDUSTRY CONNECTION 4.0 and CONECTA STARTUP BRAZIL programs. Moreover, some of them sought to encourage the participation of accelerators, support institutions, incubators, and scientific and technological institutions.

The EMBRAPII - SEBRAE Program made the participation of an accredited Scientific and Technological Institution mandatory, and in one of the support modalities, the participation of a large company in the production chain was conditioned.

The FINEP STARTUP Program, in turn, established additional scoring rules in the selection process for companies that had a commitment of a resource investment by angel investors. In addition, 
some programs combined ecosystem players' mobilization with organization of events that allowed for an optimization of partnerships' establishment among proposing companies, company accelerators, industries, in addition to introducing them to risk investors and potential customers.

\section{Conclusion}

It is understood that these initiatives present different strategies to foster innovation, outlined by means of rules and instruments, each constructed in a rational way from different views and perspectives of the actors involved in the formulation of public policies.

Given the above, it can be said that programs' effectiveness to foster innovation depends on the target sector. Since sectors that implement innovation are distinct and have their own characteristics - market, maturation term for innovation investments, amount of necessary resources - studies' elaboration considering these aspects could elucidate strengths and weaknesses of innovation strategies implemented by companies. The realization of this individual study would list particularities and real needs of each sector under study, so that such resources for fostering innovation could also find internal and external synergies to their businesses. The identification of these synergies is crucial for a public entity, sponsor of such development, in order to carry out an impact assessment, as well as an increase in social well-being resulting from the materialization of these innovation initiatives.

\section{References}

Abdi - Agência Brasileira de Desenvolvimento Industrial. (2019). Documentos. Available at: https://conectastartupbrasil.org.br/edital/. Access on: November 15, 2019.

Abdi - Agência Brasileira de Desenvolvimento Industrial. (2019). Novas possibilidades de inovação para a indústria. Available at: https:// www.abdi.com.br/projetos/startup-industria. Access on: December 04, 2019.

Abdi - Agência Brasileira de Desenvolvimento Industrial. (2019). Startup Indústria 1.0. Available at: https://startupindustria.com.br/startup1-0. Access on: December 22, 2019.

Alencar MS \& Rocha RB. (2018). Os desafios da inovação tecnológica. Revista de Tecnologia da Informação e Comunicação, 8 (1), 23-29.

Baêta AMC. (1999). O desafio da criação: uma análise das incubadoras de empresas de base tecnológica. Rio de Janeiro: Vozes

Baêta AMC, Borges C \& Tremblay DG. (2005). Empreendedorismo internacional nas incubadoras: perspectivas e desafios. Revista de $\mathrm{Ne}$ gócios, 10 (2), 76-87.

Borges DB. (2015). A subvenção econômica como instrumento de fomento à inovação e à cooperação tecnológica: Uma análise sob a perspectiva do setor empresarial. Dissertação (Mestrado). Centro de
Ciências da Administração e Socioeconômicas, Programa de PósGraduação do Curso de Administração, Universidade do Estado de Santa Catarina, Florianópolis.

Brasil. Casa Civil. (2006). Lei Complementar $n^{\circ} 123$, de 14 de dezembro de 2006. Institui o Estatuto Nacional da Microempresa e da Empresa de Pequeno Porte e dá outras providências de 14 de dezembro de 2006. Institui o Estatuto Nacional da Microempresa e da Empresa de Pequeno Porte e dá outras providências. Diário Oficial da União, Brasília, DF. Available at: http://www.planalto.gov.br/ccivil_03/leis/lcp/lcp123.htm

Centro de Gestão e Estudos Estratégicos. (2009). Os novos Instrumentos de Apoio à Inovação: Uma avaliação Inicial. Brasília. Available at: https://livroaberto.ibict.br/handle/1/679

Cni - Confederação Nacional da Indústria. (2013). Mapa estratégico da indústria 2013-2022. 2. ed. Brasília: CNI. Available at: http://www. abit.org.br/adm/Arquivo/Servico/114357.pdf

Unctad - United Nations Conference on Trade and Development. (2018). Technology and innovation report 2018 - harnessing frontier technologies for sustainable development. Genebra: UNCTAD.

Embrapii - Empresa Brasileira de Pesquisa e Inovação Industrial. (2019). Apoio à inovação para micro e pequenas empresas e microempreendedores individuais. Available at: https://embrapii.org.br/apoioa-inovacao-para-micro-e-pequenas-empresas-e-microempreendedores-individuais/

Endeavor Brasil. (2014). Como o Vale do Silício se Tornou o Vale do Silício? Três surpreendentes lições para outras cidades e regiões. Available at: http://info.endeavor.org.br/ebook-vale-do-silicio .

Enap - Escola Nacional de Administração Pública. (2016). Ações premiadas no $20^{\circ}$ Concurso Inovação na Gestão Pública Federal 2015. Brasília: Enap

Etzkowitz, H. (2013). Hélice tríplice. Universidade-indústria-governo: inovação em movimento. Porto Alegre: EDIPUCRS

Finep - Financiadora de Estudos de Projetos. (2019). Finep Startup. Available at: http://www.finep.gov.br/apoio-e-financiamento-externa/programas-e-linhas/finep-startup

Freeman C \& Soete L. (2008). A Economia da Inovação Industrial. Campinas: Editora da Unicamp.

Freitas MM \& Muylder CF. (2010). Inovação e empresa de base tecnológica: estudo bibliometrico: Seminários de Administração, Available at: http://sistema.semead.com.br/13semead/resultado/trabalhosPDF/259.pdf

Gil AC. (1999). Métodos e técnicas de pesquisa social. 5. ed. São Paulo: Atlas.

Ibge - Instituto Brasileiro de Geografia e Estatística. (2014). Pesquisa de inovação tecnológica. IBGE, Rio de Janeiro. 
Ibge - Instituto Brasileiro de Geografia e Estatística. (2017). Pesquisa de inovação tecnológica. IBGE, Rio de Janeiro.

Jaroszewski CR (2018). Os governos estaduais e a política pública de inovação tecnológica: análise a partir do modelo teórico de Hélice Tríplice. Tese (Doutorado) - Curso de Administração Pública e Governo, Fundação Getúlio Vargas, São Paulo.

Lee KF. (2019). Inteligência Artificial: Como os robôs estão mudando o mundo, a forma como amamos, nos relacionamos, trabalhamos e vivemos. Rio de Janeiro: Globo Livros.

Mazzucato M. (2011). O estado empreendedor: desmascarando o mito do setor público vs. setor privado. 1.ed. São Paulo: PortfolioPenguin

Minayo MCS. (2001). Pesquisa social: teoria, método e criatividade. Petrópolis: Vozes.

Mcti - Ministério da Ciência, Tecnologia e Inovação. (2010). Plano de Ação em Ciência, Tecnologia e Inovação 2007-2010 - Principais Resultados e Avanços. Brasília: MCTI.

Mcti - Ministério da Ciência, Tecnologia e Inovação. (2011). Estratégia nacional de ciência, tecnologia e inovação 2011-2015. Brasília: MCTIC.

Mcti - Ministério da Ciência, Tecnologia e Inovação. (2016). Estratégia nacional de ciência, tecnologia e inovação 2016-2022. Brasília: MCTIC.

Porter ME. (1999). Competição: Estratégias Competitivas Essenciais. Rio de Janeiro: Campus.

Ribeiro ARB, Silva FF, Santos MVN \& Barbosa CF. (2016). Fatores que contribuem para o sucesso de empresas de base tecnológica: um estudo multicascos em incubadoras de Pernambuco. Revista eletrônica de Estratégia de Negócios 9 (2), 208-233. http://dx.doi.org/10.19177/ reen.v9e22016193-220

Santana JR, Teixeira AL, Esperidião F, Rapini MS \& Espiridião F. (2019). Financiamento público à inovação no Brasil: contribuição para uma distribuição regional mais equilibrada. Planejamento e políticas públicas 52, 355-287. Available at: https://www.ipea.gov.br/ppp/index.php/PPP/article/view/796
Schumpeter JA. (1982). Teoria do desenvolvimento econômico: uma investigação sobre lucros, capital, crédito, juro e ciclo econômico. São Paulo: Abril Cultural.

Sebrae. (2019). Como conseguir aporte financeiro para seu projeto de inovação. Available at: https://www.sebrae.com.br/sites/PortalSebrae/ artigos/como-conseguir-aporte-financeiro-para-seu-projeto-de-inovacao,a8c3a27e0206c510VgnVCM1000004c00210aRCRD.

Senor DE \& Singer S. (2011). Nação Empreendedora: O milagre econômico de Israel e o que ele nos ensina. São Paulo: Editora Évora.

Small Business Inovattion Resources. ABOUT. Available at: https:// www.sbir.gov/about

Softex. Associação Para Promoção da Excelência do Software Brasileiro (2019) -Programa Brasileiro de Aceleração de Startups. Available at: https://softex.br/inovacao/startupbrasil

Suzigan W \& Furtado, J. (2006). Política industrial e desenvolvimento. Revista de Economia Política 26 (2), 163-185. Available at: https:// www.scielo.br/pdf/rep/v26n2/a01v26n2

Tumelero C. (2012). Sobrevivência de empresas de base tecnológica pós-incubadas: estudo da ação empreendedora sobre a mobilização e uso de recursos. Dissertação (Mestrado). Faculdade de Administração, Economia e Contabilidade. Programa de Pós-Graduação do Curso de Administração, Universidade de São Paulo, São Paulo. Disponível em: http://goo.gl/8Rv6be

Tidd J, Bessant J \& Pavitt K. (2009). Gestão da Inovação. 3. ed. Porto Alegre: Bookman.

Trott P J. (2012). Gestão da Inovação e Desenvolvimento de Novos Produtos. 4. ed. São Paulo: Bookman

Viotti EB. (2008). Brasil: de política de C\&T para política de inovação? Evolução das políticas brasileiras de ciência, tecnologia e inovação. In: Velho L.; Souza Paula, M C. Avaliação de políticas de ciência, tecnologia e inovação: diálogo entre experiências internacionais e brasileiras. Brasília: Centro de Gestão e Estudos Estratégicos. 
